\title{
RESIDENTIAL ASPIRATIONS AND PERCEPTION OF RURAL YOUTH OF THE OPPORTUNITIES OFFERED BY THEIR ENVIRONMENT: THE CASE OF A SPANISH INLAND RURAL AREA
}

\author{
José Javier Callejo González¹, Jesús Antonio Ruiz Herrero², \\ Ricardo Jiménez Aboitiz ${ }^{3}$
}

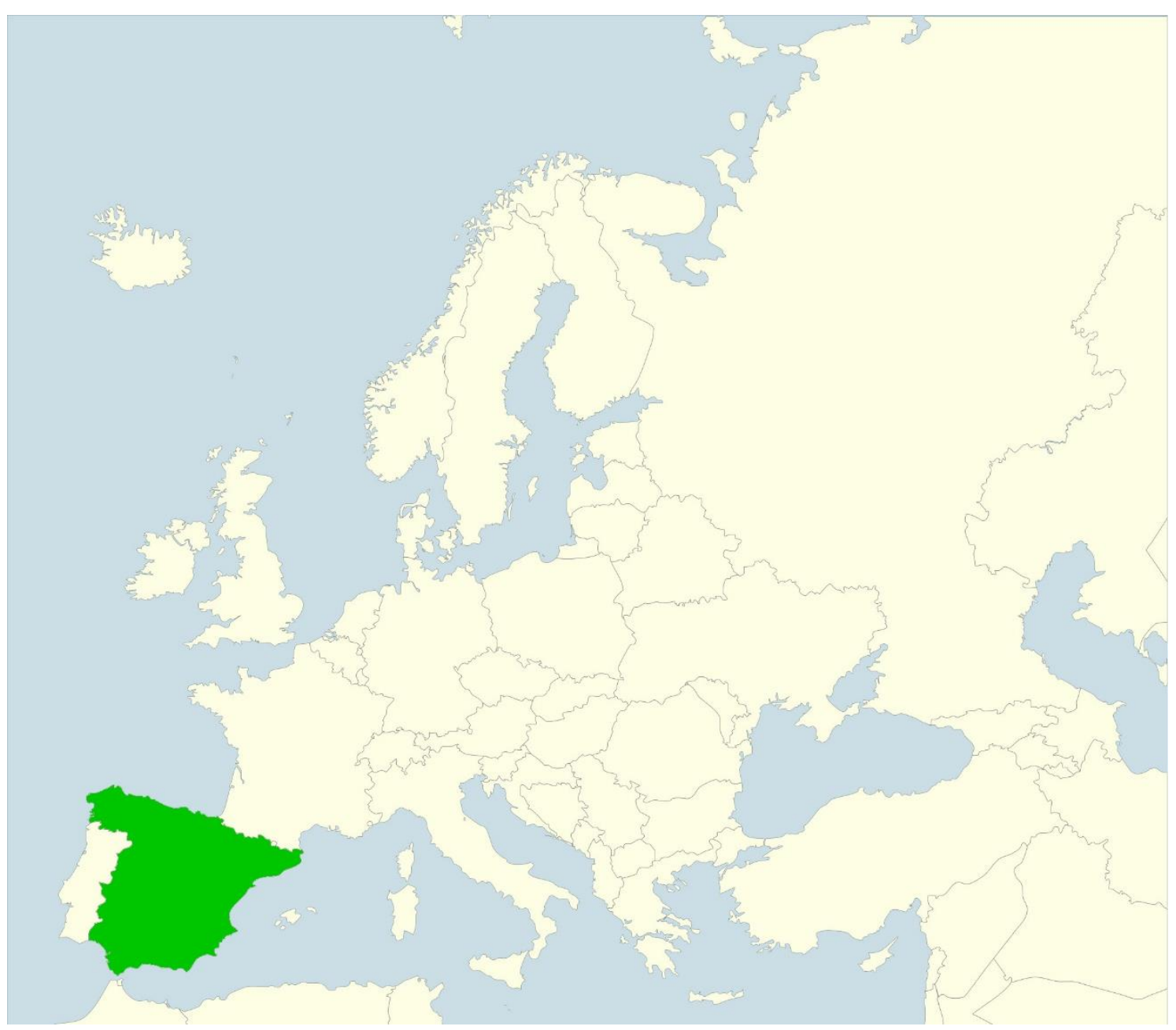

\footnotetext{
1 José Javier Callejo González, PhD in Sociology and Lecturer at the University of Valladolid, Spain. ORCID: 00000002-3982-2250, e-mail: josejavier.callejo@uva.es

2 Jesús Antonio Ruiz Herrero (corresponding author), $\mathrm{PhD}$ in Sociology and Associate Lecturer at the University of Valladolid, Spain. ORCID: 0000-0002-3695-0011, e-mail: jesusantonio.ruiz@uva.es / ruiherre@live.com

3 Ricardo Jiménez Aboitiz. PhD in Sociology and Lecturer at the University of Valladolid, Spain. e-mail: ricarjim@eco.uva.es
} 
Abstract: This study explores aspects which influence whether young people decide to remain in a rural area or move away. Based on a qualitative analysis of 41 open-ended interviews with young people from a rural area of inland Spain, it especially examines the perception they hold of the opportunities provided by their rural environment for labour market integration. The results show that: 1) agriculture, the economic base of the area, is not perceived as a means of social and labour market integration; 2) a high degree of mobility between the village and the city is a necessary condition for young people to remain in a rural area; 3) promoting the natural and cultural resources of an area strengthens the feeling of belonging and identity.

Keywords: rural youth, qualitative analysis, rural abandonment, mobility

Resumen: El estudio explora qué aspectos influyen en la decisión de los jóvenes de permanecer o abandonar el medio rural. A partir de un análisis cualitativo de 41 entrevistas abiertas con jóvenes de una zona rural de la España interior, examinamos concretamente cómo perciben estos jóvenes las oportunidades que les ofrece el medio rural para su integración laboral. Los resultados muestran lo siguiente: 1) la agricultura, base de la economía de la zona, no se percibe como un medio de integración sociolaboral; 2) un alto grado de movilidad entre el pueblo y la ciudad se considera una condición necesaria para permanecer en el pueblo; 3) promover los recursos naturales y culturales de la zona refuerza el sentimiento de pertenencia y la identidad ligada a ella.

Palabras clave: juventud rural, análisis cualitativo, abandono del medio rural, movilidad

\section{Highlights:}

- Complementarity between economic and cultural factors in the rejection of agriculture as a means of labour market integration.

- A high degree of mobility is a necessary condition for young people to remain in a rural area.

- Though efficient, job creation policies alone are insufficient to persuade young people to stay.

- Some post-materialist aspects of modern culture can be better expressed in a rural setting.

- There is a clear need to foster and promote a modern rural culture.

\section{Introduction}

The economic and social transformations that resulted from the industrial revolutions have brought about an intense process of urbanization and a parallel crisis of rural society. According to the UN (2019), the number of people presently living in urban areas corresponds to $55 \%$ of the world's population and is forecast to rise to $68 \%$ by 2050 .

Exacerbated by the trends of an ageing population and its abandonment by young people, the crisis experienced by rural society in developed countries continues unabated. Accounts of such trends can be found in the literature for countries as diverse as Russia (Mamonova, 2016), Australia (Argent \& Walmsley, 2008) or the US (Albrecht, 1998).

Extensive areas within the EU are also experiencing this demographic crisis (King, et al, 2006; Margaras, 2016; Stockdale, 2006). Studies have been published on the migration of youth from rural areas in numerous countries, including Estonia (Trell et al., 2012), the Netherlands and Belgium (Thissen et al., 2010), Germany (Wiest, 2016), Turkey (Öztürk et al., 2014) and Spain (Atance et al., 2010; Recaño, 2017). However, the process that is involved is by no means 
uniform. In some countries, potential sources of rural population growth have been detected in the shape of the so-called baby-boomers, once they retire, and immigrants from peripheral economies (Collantes et al. 2014; Donato et al., 2007; Niedomysl \& Amcoff, 2011). Meanwhile, in other countries, policies have been successfully implemented for the resettlement of rural areas, as in the case of Scotland or Scandinavia (Pinilla \& Sáez, 2017).

However, if such policies are to be effective, they also need to be based on an exhaustive knowledge and understanding of the reasons that impel young people to leave behind their rural environment and the factors that could potentially persuade them to stay.

Such an understanding requires analysis not only of factors of a structural nature, which have been extensively considered in the literature (ESPON, 2018; Shaw, 1979; Tickamyer \& Duncan, 1990), but also of the perception held by these same young people of their rural environment. For them, such perceptions and evaluations are decisive when choosing whether to stay or leave (McLaughlin, et al., 2014; Rudkin, et al., 1994). Based on this premise, the present paper aims to explore and analyse the perception that young people from a particular rural area in Spain have of such 'stay or leave' factors. Firstly, we consider the main factors that have been reported in the literature to affect the decision of young people to stay in or abandon their rural habitat. Secondly, we contrast these factors with the perception held of them by the youth of a particular area of Spain, Valladolid province ${ }^{4}$. A prior description is also given of the study area and the methodology employed.

\section{The rural youth: 'stay' or 'leave' factors}

Multiple and diverse causes and factors are involved in the migration of young people from rural areas.

A first important factor can be found in the transformations currently taking place in agriculture, which remains the economic mainstay of rural society in many regions. The use of new technology in production methods, the concentration of agricultural holdings and the significant impact of large corporations, have all contributed to the development of an agro-industry, which has resulted in fewer direct and indirect job prospects in rural areas. To this, it can be added the problem of a lack of alternative employment as, for example, jobs associated to the service industry overwhelmingly tend to be situated in cities (Argent \& Tonts, 2015; Argent \& Walmsley, 2008; Elder \& Conger, 2000). These processes have moreover been compounded by the economic crisis of 2008, with global financial capital opting, to an ever-growing degree, to invest in the agri-food industry and primary activities (Clapp, 2014).

In the case of Spain (Camarero, 2017: 174), the modernization of agriculture is giving rise to two types of farming: 1 ) intensive fruit and vegetable production, with highly variable labour demands and mainly located along the Mediterranean coast; 2) extensive industrial production (mainly cereal crop cultivation), with an increasingly declining dependence on labour and principally found in inland Spain where the most depopulated rural areas are concentrated (the villages where the interviews of the present study were carried out are a good example of such areas). In addition, the effects on this dynamic of successive EU common agricultural policies (CAP) cannot be ignored. While such policies may have succeeded in making the farming sector more competitive, not only have they failed to stem the depopulation flow in rural areas, paradoxically, they may have even accelerated it (Arnalte, 2002; González Regidor, 2017; Terres et al., 2015).

Apart from these economic factors, cultural factors should also not be ignored. As Bæck (2004) or Argent \& Walmsley (2008) point out, the view of rural youth that the space they inhabit fails to stimulate them is just one example of an extended mindset among young people that idealizes life in the city with its accumulation of the symbols of a global mass media-spread culture (Farrugia, 2016). It is therefore unsurprising that many children brought up in a rural environment express a feeling of geographic and social isolation, especially if they live in sparsely populated areas (Cummins, 2009), that could lead them to leave in the future.

\footnotetext{
${ }^{4}$ In Spain, a province is an administrative territorial unit. Spain is divided into 52 provinces, as can be seen in Figure 1.
} 
Reducing urban and rural differences through the development of out-of-town shopping centres or other leisure facilities (Omelchenko \& Poliakov, 2018) could potentially moderate that feeling of isolation or help youths reassess the value of a rural environment, at least in terms of satisfying their desire to experience the most fashionable leisure options of the moment. Adequate Internet accessibility would also allow young people to participate in global and virtual communities described by Farrugia (2016; et al. 2014) as "symbolic mobility" - and again moderate that feeling of isolation and the desire to emigrate.

Other 'leave' factors for rural youth are associated with social mobility. Kirkpatrick et al. (2005) found that the perception young people hold of a lack of opportunities in rural environments, especially if they aspire to a university education, encourages their migration to cities, whereas identifying with their parents or a positive evaluation of rural-based occupations and lifestyle have the opposite effect.

The decision to stay in or leave a rural area can also be swayed by gender-related factors (Pini \& Leach, 2011). Some studies highlight the feeling of young women that they are subjected to greater social control in rural environments, with this being a particularly important 'leave' factor for them (Glendinning et al., 2003). Dahlström (1996) also found that young women were more predisposed to move to urban areas because of their far stronger desire for a successful academic and professional life in comparison with their male counterparts. The reason for this difference may lie in the fact that rural environments tend to be socially and culturally modelled in accordance with male perspectives (Nuttall, 2000) encouraging women to migrate to cities and to place a high degree of importance on academic achievement as means to self-promotion (Ames, 2013; Sampedro, 2000).

The question of identity also plays a vital role. The fact that the traditional cultural patterns of the rural world have virtually disappeared has weakened the feeling of belonging and favoured its abandonment (Cuervo \& Wyn, 2012). As Carr \& Kefalas (2009) or Corbett (2010) report, often the agents of socialization (family, teachers, etc.) of the rural community itself even initiate such a process by implying to the younger and brighter students that, for them, staying is the soft option. Other studies highlight the impact in rural environments of a cultural mindset which is dominated - as the result of migration and ageing - by middle and older age groups. Such a mindset may attach little importance to the concerns of the younger generations and contribute to their feeling of alienation, acting as an additional 'leave' factor (Leyshon, 2011; Pedersen, 2018).

In contrast to the above 'repressions', other studies point out that villages and rural life in general offer a more extensive leisure space (Abbott-Chapman \& Robertson, 2015), resulting in youths potentially feeling greater 'freedom' as, for example, they encounter less stressful spaces or are able to satisfy certain habits such as the practice of outdoor sports (Farrugia, Smyth, \& Harrison, 2016; McLaughlin et al., 2014). In contrast, the city, with all the insecurities it generates in many youths and the rigidity displayed in the planning of its spaces (Certeau \& Rendall, 1988: 94), does not allow such 'freedom'.

The above aspects are related to the traditional issue of quality of life in a rural setting (the rural idyll). Some authors underline the perception of the countryside as a harmonious and safe environment, which is therefore considered suitable for family life and the raising of children (Bernard, 2019; Halliday \& Little, 2001; Powell, et al., 2013). In contrast, the shortage of affordable housing and the absence of adequate transport services have the opposite effect (Gabriel, 2002; Rugg \& Jones, 1999; Storey \& Brannen, 2000).

Finally, according to some authors, the comfort and protection offered by a close-knit rural community can instil a psychological feeling of well-being in young people, acting as a 'stay' factor (Cook \& Cuervo, 2020; Glendinning et al., 2003). However, other studies argue that while the trust that is generated among neighbouring adults of a certain age may encourage people to stay in the village, this is not necessarily the case for the younger generations (Trell et al., 2012; UlrichSchad et al., 2013).

In short, the research studies that we have analysed try, on the one hand, to explain why young people continue to abandon rural areas and, on the other, to identify those factors which might 
persuade them to stay, especially in a context in which large cities, most notably in Mediterranean countries, are showing signs of labour market saturation (Carlucci et al., 2017).

The purpose of this paper is to contribute to these questions based on an analysis of the perception that young people - living in a typical rural area of inland Spain - have of the factors likely to encourage them to stay or leave, and the impact that this perception has on their residential aspirations.

\section{Study area and methodology}

The rural area that is the object of the present study, the province of Valladolid, forms part of the Autonomous Community of Castilla y León, one of the most depopulated regions of Spain (see Figure 1 on the next page).

Rural areas in Spain are not homogenous. Major contrasts exist there between, for example, the rural areas close to Madrid or Barcelona or along coastal regions, which display considerable economic-demographic dynamism and those situated in what is known as 'inland Spain', which includes the study area. These latter areas have suffered heavy migration to the industrial poles since the 1960s, resulting in low population densities, markedly ageing populations, and a high degree of dependency on the primary sector. In consequence, such areas score highest on the so-called 'rurality index' in Spain (Prieto-Lara \& Ocaña-Riola, 2010). Hence the interest in their study and, more specifically, the phenomenon of the migration to cities of their rural youth.

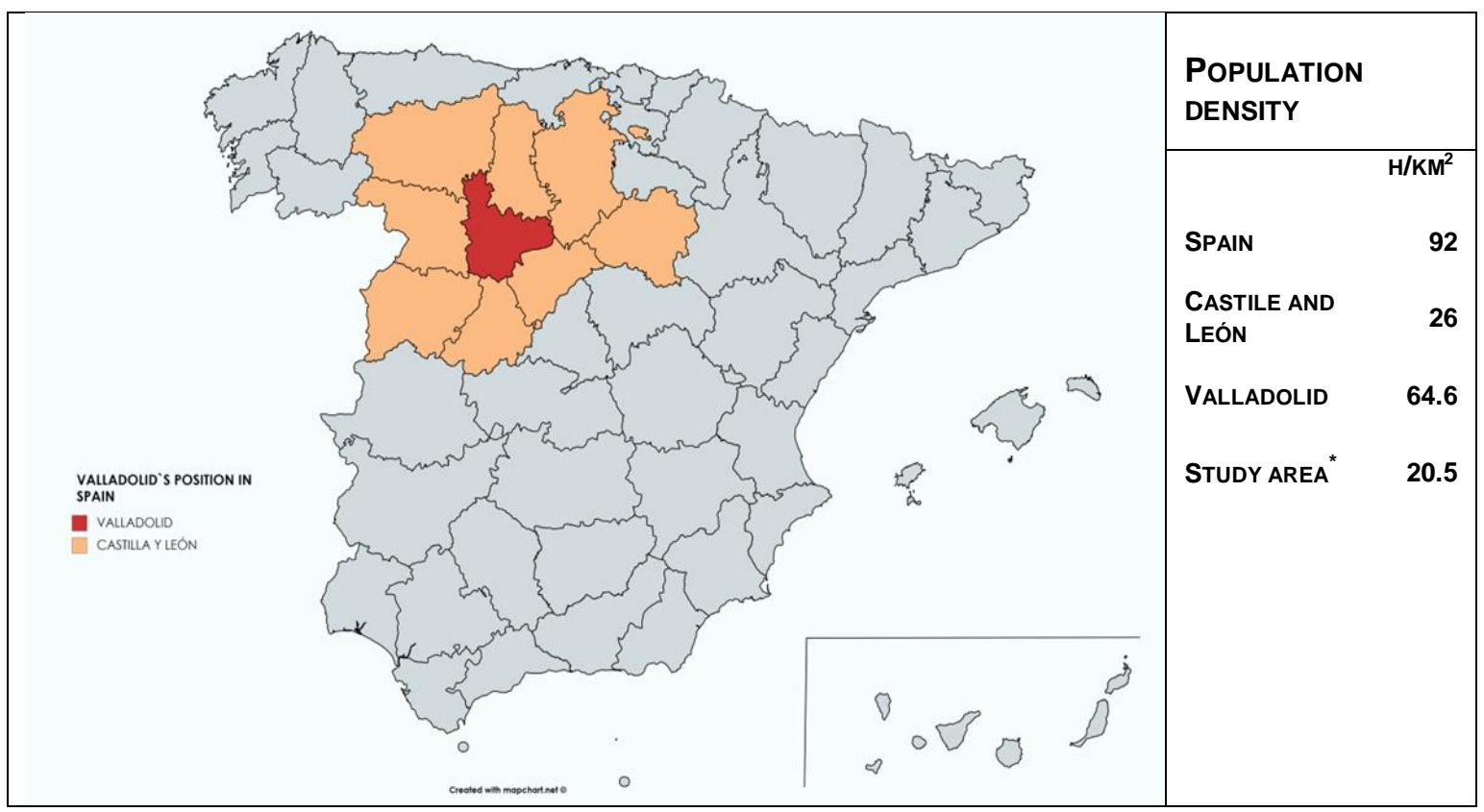

Fig 1. Population density. Spain, Castile and León, Valladolid. 2017. Source: Own elaboration based on the 2016 Castile and León Statistical Yearbook

* The capital of the province and two municipalities with more than 20,000 inhabitants were excluded from the study

Another defining feature of these inland areas is the low rate of diversification in the primary sector. In fact, in recent decades, most of the rural areas of Valladolid province have seen the growing predominance of extensive arable crop cultivation. This has resulted in intensive mechanisation of the agricultural sector and a consequent substantial reduction of the active population employed in it. The disappearance of jobs in the primary sector has augmented the decline of the activity in other sectors in the rural world.

To pursue the aim of this study, a qualitative methodology was employed in combination with a discourse analysis along the lines proposed by Conde (2009), who defends firstly capturing the overall sense of the discourse of each interviewee, and its more important meanings (semantic attractors), in order to situate it in a position - in our case, those who wish to abandon or remain in their rural dwelling, etc. - followed by a more in-depth analysis of what each of these 
positions is related to (social climbing projects, lifestyles that commit to the urban world, etc.). We also follow the proposal of Gibbs (2007) of searching for patterns in the discourses by groups (men vs. women, offspring of landowners/non-landowners, etc.) in order to find explanatory clues. Based on this perspective, a total of 41 youths from the study area, aged between 24 and 29 and from both sexes, were interviewed in early 2017 using an open-ended interview technique ${ }^{5}$. This age group was chosen as it is when (later than in the rest of Europe) the majority of Spain's young people face the challenges posed in gaining independence from their parents (Injuve, 2021:113) and is therefore the time when they ponder with greater intensity whether they should remain in or abandon their village and rural life.

By way of clarification as to the lateness in terms of age of the emancipation of Spanish youths, it should be noted that this has been the case since the 1980 (Moreno, 2018). In 2017, when the interviews were held, the average age of emancipation for Spanish youths was 29.3, only exceeded in Europe by other southern countries, namely Greece (29.4), Italy (30.1) and Montenegro (32.5) (Eurostat, 2021a).

While there are multiple factors involved (Moreno, 2018), the most important is undoubtedly the high unemployment rates and temporary nature of the Spanish labour market. Eurostat data (2021b) showed in 2017 a 20\% unemployment rate for youths in the 25-29 age bracket, compared to the European average of $9.5 \%$ and exceeded only by Greece. At the same time, $48.9 \%$ of the youths with work were on short-term temporary contracts compared to the European average of $22.4 \%$ (Eurostat, 2021c). Deindustrialization, the expansion of medium and low added value services and so-called work 'flexibilization' help to explain the situation of the Spanish labour market (Garrido et al, 2020).

The unemployment rate in the 16-29 age bracket in Castilla León, the region in Spain where the present study was carried out, was $26.4 \%$ in 2017 compared to the mean rate of $29.4 \%$ in Spain and the European average of 13.2\% (EU 28) (FAD Reina Sofía, 2021a). Likewise, in the same year, temporary contracts were the norm for $60.3 \%$ of working youths in Castilla y León compared to a national average of $57.5 \%$ and a European average of $32.5 \%$ (EU 28) (FAD Reina Sofía, 2021b). It is in this difficult context that the rural youth of Valladolid construct their hopes and expectations as well as their emancipation strategies.

The sample was selected purposively on the basis of a combination of two structural criteria, educational attainment and employment status, which taken together may have a significant influence on the residential aspirations of young people. Table 1 shows the distribution of the interviewees broken down according to the different categories defined by the aforementioned criteria.

Tab 1. Qualitative sample of young people interviewed broken down according to different profiles.

EMPLOYMENT STATUS

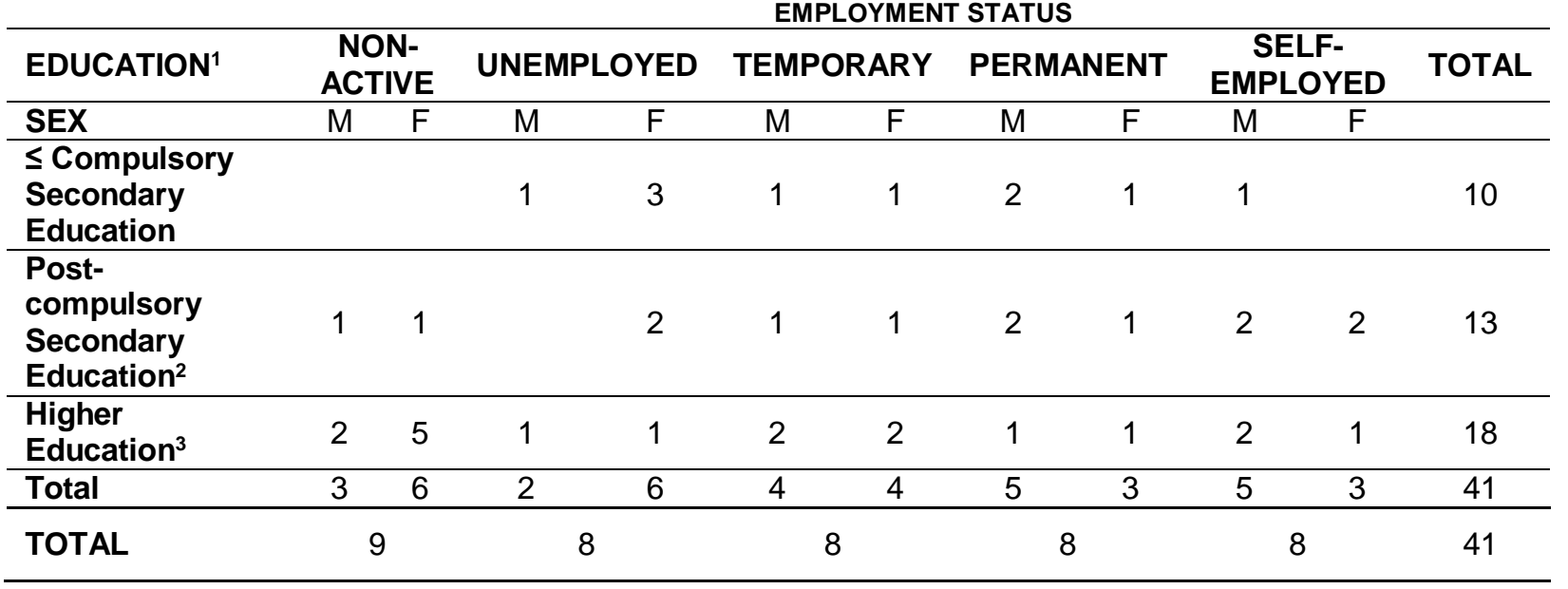

1. Level achieved independently of whether a higher level has been initiated or not

2. Eleven with an Intermediate Vocational Training Diploma, and two with a High School Diploma

3. Fifteen with University Studies and 3 with Higher Vocational Training Diploma

${ }^{5}$ This study complied with all ethical requirements, such as informed consent. 
Interviewees were accessed through the mediation of rural youth workers. It is possible that this contact strategy favoured access to young people with more social relations or closer to local institutions, although a wide range of social and personal situations were accessed, as shown in the table.

All 41 interviewees grew up in the rural area considered in this study. Of these, 32 presently live there while the remaining 9 are temporarily living in the city for work or study reasons. With respect to the future, 19 intend to continue living in the country while the other 22 plan to move permanently to a city.

The notes used in the interviews included the following thematic dimensions: academic career, employment history, perception of opportunities for social integration offered by the rural environment of the interviewee, and residential aspirations. Questions about future living plans are relevant as it has been shown that the responses act as an effective predictor of real and definitive migration (van Dalen \& Henkens, 2013).

With respect to the analytical framework, the interviews were first read in their entirety in order to establish the main groups, those who wish to remain and those who wish to leave. Following this, and proceeding from a general to a more particular analysis (Conde, 2009; Ricoeur 1976), an indepth study was undertaken of the specific factors that the interviewees recognised as being relevant in their plans to stay or leave and of the cultural meanings that they use to speak about those plans. We assessed whether the factors indicated by the interviewees coincided with those highlighted in the studies that were consulted in the literature search. Nonetheless, other emerging factors were also considered which could be affecting their plans (Timmermans and Tavory, 2012), as well as contextual influences (Fairclough 2003: 123-133) like the still ongoing impact of the financial crisis of 2008.

\title{
4. Results: perception of opportunities in a rural environment
}

The interviewees' overall impression was that economic dynamism in their rural area was low and that there were few opportunities for their integration in the labour market. Along with this general perception, the interviewees also expressed a more specific assessment of the different factors present in the areas they came from which affected the likelihood of their integration in or outside it: agriculture, industry, services, education and training, new job sources and lifestyle.

\subsection{Agriculture and livestock farming}

Agriculture and, to a lesser extent, livestock farming, constitute the main economic activity of the study area. In Spain, this sector has undergone a severe process of modernisation, mechanisation and resizing in recent decades. While this may have made it more competitive, it has also meant a significant reduction in the number of agricultural holdings and in the active population employed in the sector.

Young people are fully aware of these changes and recognise the economic importance of agriculture in the area where they live, but do not see this activity as part of their life project, nor as a means of social and labour market integration. Both socio-economic and cultural questions are cited as reasons for its exclusion.

\begin{abstract}
Q - "Are there a lot of people working in agriculture?"
$R$ - "A few, yes, but older people... like the 70-year-old father of someone I know. The odd son has hung around, but others have moved away and found different work elsewhere. Some people have jobs in agriculture, but not many and the numbers are getting less and less".
\end{abstract}

(Female ${ }^{6}, 28$, Higher Vocational Training Diploma in pre-school education, temporary work as pre-school supervisor, Interviewee 15).

\footnotetext{
${ }^{6}$ In all quotes, the gender, age and educational and employment situation of the interviewee is provided, as well as the interview number.
} 
Young people consider that a career in agriculture is not possible without an initial and substantial economic input, specifically in land. This considerably limits their options in the majority of cases, and seems to only be feasible for the children of medium and large landowners:

"Starting off as a farmer without anything is very difficult. You have to invest a lot of money. Mind you, if your grandpa had some land, or your father or even your greatgrandfather, well that might make a difference."

(Male, 27, Compulsory Secondary Education, permanent contract in construction, 113)

In addition, in the opinion of the interviewees, agriculture is not even an attractive option for young people who come from farming families and who could potentially inherit land. The explanations given for this lack of interest in agriculture commonly allude to its being an essentially rural activity and hence its traditional close association with village life.

"It's not that agriculture itself isn't an attractive option, it's the fact, I reckon, that they (young people) don't fancy village life as there just aren't as many amenities as you can find in the city..."

(Female, 27, University Studies in pre-school teaching, studies and works in the hotel trade, 17)

The parents themselves, even those who are farmers, tend to inculcate in their offspring the idea that they should not work in agriculture, not necessarily because it is an economically unattractive option but rather because it is symbolically less prestigious than other professions associated with university degrees. In the same line, agriculture does not appear to be considered, in the cultural tradition of the province, a suitable economic activity for women from the area, which induces them to reject it.

Q- There's a lot of agricultural activity around your village, although very few women work in that profession. Why not?

$R$ - Well, I don't really know, I reckon because it's always been considered a job for men.

(Female, 28, Higher Vocational Training Diploma in pre-school teaching, temporary work, 115)

Although the young interviewees are aware that the modernisation of agriculture in the area is one of the key factors in its depopulation, they do not display a critical attitude to such a growth model. On the contrary, they see it as part of economic progress, and the consequent reduction in employment opportunities as an inevitable effect.

\subsection{Industry, services and tourism}

The industrial sector does not play a prominent role in the study area, with the little industrial activity that there is concentrated in the capital of the province and some nearby villages/towns. As a consequence, the interviewees do not contemplate industry as a very realistic means of social integration in their village.

Conversely, in villages/towns in which an industrial fabric of one sort or another has existed, the fact that job opportunities in the sector are few and far between is directly put down to the economic crisis that Spain has been affected by since 2008 and to the extremely low number of companies willing to set up business in the area.

"There were tons of work. It was when the crisis started that things began to go to pot. In fact, I started at just about the time the crisis began. The first big company that was here closed four months after I had a business transferred to my name... It was a massive blow."

(Female, 28, Intermediate Vocational Training Diploma in administration, selfemployed, painting and decorating business, 119) 
On the other hand, the few young people who have worked in the declining rural industry tend to be male and working class (or with no university education). Consequently, work of this type does not constitute a powerful factor of attraction, except maybe for a few very specific profiles. In contrast, the preference of most of the interviewees is for a service profession, which tends overwhelmingly to see them head off to cities. In this respect, most of the interviewees consider the possibility of finding work in the service sector of these rural areas to be remote. As far as they are aware, there are very few service-based companies, and those that do exist already have any job positions filled. At the same time, they see little feasibility in opening their own business given the sparse population and, therefore, the low numbers of potential clients.

$$
\begin{aligned}
& Q-\text { "Would it be difficult to set up a business here?" } \\
& R-\text { "It certainly wouldn't be easy because there are less people all the time and, in } \\
& \text { the end, you come here [to the village] to buy something and it's always going to cost } \\
& \text { you more than in the city." }
\end{aligned}
$$

(Male, 24, Intermediate Vocational Training Diploma in mechanics, self-employed farmer, 13)

Rural tourism is a different case. This sector enjoys high visibility among young people, maybe due to the recent proliferation of short-term rental rural properties in the province's villages. Young people are also aware of the growing interest on the part of public administration bodies to promote and support rural tourism.

"The truth is that in the last few years, there's been a lot of promotion of the area... Yes, it's being promoted more, and more and more people are hearing about it and, it seems, they're coming in greater numbers than before."

(Female, 26, University Studies in architecture, self-employed architect, 15)

Consequently, the perception that most of the young people interviewed have of rural tourism is accompanied by a certain degree of optimism. Firstly, because it helps to generate a positive outlook for the local economy, and secondly, because of what it contributes at a more emotional level - namely the promotion and recognition of the scenic, gastronomic and cultural values of the area in question.

\subsection{Education and training and the qualified labour market}

Historical and cultural factors, but most notably the land property structure of the study area and its smallholding character, have meant that families who could afford to do so traditionally put their faith in a good education as the only means for their children to ascend the social ladder (Beltrán Tapia \& Martínez-Galarraga, 2015). This strategy of investment in education has been assumed by even some working-class segments, thanks to the democratisation of education:

\section{"It is indeed true that the education my parents couldn't get, a better and longer education, is something they have always wanted for us, and they've always told me to look ahead... to aim as high as possible in my studies and career." \\ (Female, 27, University Studies in chemistry, permanent contract with chemical company, 122)}

As a result of this parental/family influence, many of the interviewees have done well in their studies and achieved academic qualifications (see Table 1, p.9) that have enabled them to embark on professional careers, which would not have been possible in their rural environment. The reason lies in the otherwise scant possibility, from their perspective, of obtaining work in the village related to their level of attainment, which would allow them to make the most of their academic qualifications and achieve a better social position. In other words, the higher the academic level achieved, the greater the desire to leave. This is all the truer in the case of women who show no interest in manual jobs considered typical of the village and of men.

"Work in the countryside has traditionally been done by men, which in the end means they're the ones more likely to stay... In my village, it's the young men who are staying, 
at least those who've inherited or who have started working on their parents' land or those who have some cows or sheep... (...). If you look at people of my age, most of the girls have a university degree and most of the boys don't."

(Female, 28, University Studies in Spanish language and literature, temporary work in the communication sector, 125)

\title{
4.4 New job sources in the rural environment
}

While social and labour market integration for young people is very limited in a rural environment owing to the issues commented on above, there is some evidence in the study area of opportunities for employment that could alleviate such trends.

Local and regional administrations, following directives of the EU and their job-creation programmes, are presently generating, directly or indirectly, through business tax exemption measures or public employment programmes, a not inconsiderable number of job offers in the study area.

Given that these job offers are aimed at people who are living and resident in the area, it is relatively easy for the younger residents to access these jobs when compared to those living in cities where competition for such positions is fierce. This is certainly a factor which is likely to encourage young people to stay in the village, as the possibility of work and acquiring some experience gives them a degree of autonomy and economic independence. Additionally, it helps them avoid the despondency that tends to go hand-in-hand with long-term unemployment.

However, the nature of these work contracts, linked as they are to, for example, company tax exemptions, puts in doubt the length of time these young people will be able to continue in their positions, introducing a strong element of job insecurity and uncertainty and, most importantly, the impossibility of developing and consolidating a professional career in a specific field of work.

\begin{abstract}
$Q$ - "And so your contract finished in the nursery school and you were [let go]?
$R$ - "The fact is it was a contract that I was awarded [with tax benefits for the employer] because l'd got my qualifications in the previous six months and was younger than 30 years old, but then when you've been there a year, I think that if they want to keep you on, the company has to start paying social security taxes to the government because the subsidies have finished and there's no longer a discount for the company... I reckon they [the company] are more interested in hiring someone who meets the conditions they need so they can save on the social security payments."
\end{abstract}

(Female, 28, Higher Vocational Training Diploma in pre-school teaching, temporary work, 115)

Another source of employment is presently emerging as a direct result of the ageing of the rural population: care of old people. The very high average age of the rural population of Valladolid province has led the public administrations to promote the installation of old people's care homes in rural areas as well as set up a series of 'home care' programmes. These initiatives have meant the introduction of a new source of employment, especially for women who are more likely than their male counterparts to take on this type of occupation due to gender expectations.

"For example, in my village, there are five or six women who had never had a job and now they're working in a care home for old people. They did a course that was advertised, I don't know if it was run by the provincial government or something, and, look, that's where they are now".

(Female, 24, Intermediate Vocational Training Diploma. Lab Technician, unemployed, 129)

This type of employment is also important for its contribution to the generation of more genderbalanced employment opportunities in rural areas, counteracting the effects of a male-oriented labour market, as found in the literature review described earlier. 
At the same time, it should be noted that this is not yet a very important factor in persuading young females to remain in their rural environment as their observations are related not so much to job opportunities for themselves but rather for slightly older females from the age of 40 onwards who are looking for ways to supplement the family income.

Finally, to close this point, the village offers some job opportunities that are not available in the city. Various examples were found through the interviews of young people who, having initially opted for work in the city, have decided to return to the village because of the precarious nature of the labour market and/or the opportunity to take over or expand a family business.

$$
\begin{aligned}
& R-\text { "It's not that I didn't like the work but what happens is that the boss and that, } \\
& \text { well... in the end that's what wears you down, they demanded more... more than they } \\
& \text { gave." } \\
& Q \text { - "They didn't convince you then, the conditions at...[work]?" } \\
& R-\text { "No, no. I said that there was something that ought to be changed, the boss didn't } \\
& \text { agree, and in the end..." } \\
& Q-\text { "So, you left and decided to come back to the...[village]?" } \\
& R-\text { "Yes, exactly. If I was going to leave the city then it was to come back to } \\
& \text { the village, right." }
\end{aligned}
$$

(Male, 27, Intermediate Vocational Training Diploma in electronics, self-employed farmer, 16)

\subsection{Rural life and urban culture as determining factors in migration processes}

Another important aspect affecting the residential aspirations of rural youth is the desire to adopt a similar lifestyle to that followed by urban youth (Camarero, 2000; Farrugia 2016; Sampedro, 2008: 180). In other words, young people want to leave their village not only because of the lack of job opportunities. The social values and needs that the rural youth are acquainted with have been established by a dominant urban culture, which symbolically portrays the rural world as deficient compared to a big city in terms of service, recreational spaces or meeting places.

At the same time, in this context, the typical activities of the countryside and rural life are unappealing to young people.
"Because, as well, it's a job [farming] that you do on your own, and you only speak with other farmers, you don't get to know anybody either... Well, right now I don't fancy it. Maybe in ten years'time or so l'll say: "ok, look, l'm going back to the village». Perhaps, then ... But at the moment, when I'm 25 years old, no thanks."
(Male, 25, University Studies in physical education and sports science, preparing to sit public examinations, 120)

This complex conceptualisation of rural villages as lower quality places culminates in a perception among young people that the decline of the rural environment is a natural process and something inevitable.

$$
\begin{aligned}
& Q-\text { "In } 15 \text { or } 20 \text { years, what do you think will happen?" } \\
& R-\text { "Oh, goodness me, I don't really know... But if things carry on the way they are } \\
& \text { now...., at the same rate, a lot of people... a lot will be leaving." } \\
& \text { (Male, Compulsory Secondary Education, unemployed, 114). }
\end{aligned}
$$

It should be noted that the vison of the village as deficient not only responds to the seductive power of the city, as most interviewees acknowledge that villages are worse equipped servicewise. However, those who are determined to stay try to adapt to the services that do exist, revealing that the strong emotional bond to the place is a factor that can counterbalance the perception of disadvantages. Furthermore, they try to mitigate the service disadvantage factor through something that has become an indispensable condition for guaranteeing their 
continuance in the village - mobility. Therefore, for rural youngsters, a car is an absolute necessity. Good means of transport, but especially a privately owned car, allow people to live in a village without having to give up the services and opportunities found in a city. Most importantly, they also reduce the feeling of isolation that can be so ingrained in rural youth.

$R$ - "Here in [name of village], if you don't have a car you have no life. I mean, there are no shops here, so you can't buy anything."

Q - "What trips do you make on a daily basis, or during the week?"

$R$ - "I go a lot to Valladolid (the city)..., almost every week I go to Valladolid, to Palencia." (Female, 25, University Studies in law, work experience scholarship)

Clearly, the capacity for mobility is reduced in young people with low economic resources. The concept of porosity between the rural and urban space is absent from their discourse, replaced by the idea of reclusion and a lack of opportunities.

"Everything's a lot closer at hand there than it is here. Here, to get anywhere I have to make a real effort and spend money I just can't afford and..., it's a real bother 'cos if I lived in Valladolid l'd be able to move around much easier and I know that I wouldn't have to be catching buses everywhere."

(Female, 26, Compulsory Secondary Education, unemployed, I33)

Another aspect that enables and encourages young people to stay is the feeling of belonging to rural communities. Young people who express a desire to stay in their village see it as a protective environment and commonly acknowledge their participation in mutual support networks which foster social harmony. Such networks create social bonds and emotional ties, which can contribute to helping a young person to decide to stay in his or her rural environment.

"(...) me too, in a small group of people of my age and a bit older, we saved and took over the running of a youth association which had been virtually forgotten about and organised a whole load of activities, fun runs for example, and we even dressed up as the Three Wise Men for the Epiphany celebrations (...)"

(Male, 27, University Studies in agronomy, self-employed farmer, 12)

Some of the young interviewees tended to compare the pace of village and city life, preferring the peace and quiet of the former, quite simply because they are looking for a relaxed environment to live in as opposed to the stress of an urban existence.

"Well, in a city, you can do the same stuff as in a village, but it's a lot more stressful: the traffic, the noise, the peak hours... Me, the city, I associate it with stress; the village, with peace and quiet".

(Male, 27, Compulsory Secondary Education, permanent contract in construction, 113)

Another aspect that is well considered and highlighted by the young interviewees who see their future in a rural setting concerns the possibilities that rural life offers them the practice of certain physical activities. This is especially true of those whose lifestyle revolves around sport and nature. Given that the practice of sport is a growing trend in society (Llopis-Goig \& Vilanova, 2015), this is very likely to fuel the potential of the village as the best place to live in the eyes of young people.

"Yes, there's a reservoir we go to every year where you can hire dugout canoes, but there are sports you can do all year round, especially racquetball and basketball."

(Male, 26, University Studies in publicity, permanent contract as receptionist in a hotel, 137).

The narrative of the village as a place in which one has a sense of freedom or where there are more possibilities for the practice of their favourite sports tends to appear fundamentally in the discourse of the male youth, who display a greater propensity than the women for the connection between village, sport and adventure. Conversely, the narrative of the village as 
a place of peace and quiet is slightly more apparent in the discourse of the women, especially in relation to bringing up children: the village, sometimes represented as an arcadian idyll, is seen as a place to bring up children that is less stressful and contains fewer hidden dangers - although this latter point needs to be countered by the likelihood of the children having to travel some distance to school, especially when they live in small villages where schools have virtually disappeared.

\begin{abstract}
"(...) then the people who have kids, well they can play in the street with no worries, go on their own to the football pitches and the courts, again 'cos there are no problems, I don't know, we all look after one another..., stuff like that."
\end{abstract}

(Female, 24, University Studies in pre-school teaching, preparing to sit public examinations, 123)

\title{
5. Discussion and conclusions
}

Unlike other studies which have preferentially focused on one single factor - mainly of an economic nature -, in this case, an extensive discourse was generated which made possible the discovery of several important elements in the decision of rural youth to stay or leave. Furthermore, numerous studies have tended to focus solely on the 'leave' factors, with relatively few, like the present study, tackling aspects which may incline young people to stay. Anyway, based on the analysis of young people's perception of what their rural environment offers them, it is clear that the 'leave' factors are more powerful than the 'stay' factors. Nonetheless, the latter offer some hope for the objective of reversing rural depopulation.

As testified to in the literature, the most prominent 'leave' factors are related to the labour market. The perception of the paucity of qualified job offers pushes young people away. The few youths who would like to work in agriculture find serious difficulties due to the high mechanisation of the agricultural sector, which reduces the demand for salaried work (Argent \& Tonts, 2015; Molinero et al., 2016). This process additionally favours the concentration of land in fewer hands and makes it more difficult for young people to access it. In this regard, modifying the CAP ensuring more support for organic farming, craftmanship trades or small agriculture and livestock farming enterprises (Molinero, 2019) - would countervail the market-based and industrialisationbased dynamics that presently dominate the agricultural sector, and which are ultimately responsible for the current rural population drain.

However, not always did the interviewees cite economic factors as the main reason for excluding agriculture from their social integration projects, which reveals a complementarity between economic and cultural factors. For instance, some young people, and especially women, tend anyway to reject agriculture, because they see it as something coarse, or are attracted by a modern urban lifestyle which the socially depressed villages cannot offer. In this respect, the promotion of agriculture (and other typical rural occupations) as a modern, qualified and socially respected profession, among both young men and women, would help to change the low symbolic value that many young people assign to it when some, in their heart of hearts, do in fact feel attracted by the idea of hands-on work (Corbett \& Corbett, 2018). The competitions that are held for primary sector entrepreneurs, often organized by the mass media, constitute a step forward in raising the profile and prestige of these activities (Castilla y León Televisión, 2021).

As regards which factors are influential in their motivation to stay, one of these is mobility, a central feature of contemporaneity (Öztürk et al., 2014; Urry, 2007). In fact, it was seen how young people who are contemplating staying in their village will always only do so when they are sure it will be easy for them to travel to nearby cities. This extends the results of Bernard (2019) or Noack (2011). The guarantee of mobility reduces the opportunity cost of living in a village (in terms of education, leisure possibilities, etc.), allowing them to enjoy the best of both the urban and the rural environment.

In fact, this constant travelling to and from the city fulfils a sort of 'alternative' city life role, as observed on occasions by Farrugia (2016) in his previously mentioned so-called "symbolic mobility". Such mobilities satisfy to some degree certain desires of young people and helps them in this way avoid the syndrome of village isolation (Cummins, 2009) and permanent migration to 
the city. For this reason, the promotion of cheap and economic transport between village and city could help persuade more young people to choose to continue living in their village. In any case, the best positioned villages in this respect (the mobility factor) are those closest to the city, with the consequent lower costs and travelling times.

The possibilities of frequent physical mobility between village and city are much higher in the rural area considered in the present study, where the longest distance does not exceed 100 kilometres, than, for example, in Australia or Canada where the nearest city may be hundreds of kilometres away (Kilpatrick et al., 2011; Veitch, 1995). This aspect is specific to the Spanish rural context, as well as some other parts of Europe, where rural and urban worlds are more porous and young people are more mobile and enjoy more 'hybrid' identities (Ghannam, 2011).

Other significant 'stay' factors include the existence of state-paid or state-subsidised jobs and the emergence of new employment sources in the form of the care of old people linked to the intense aging of the rural population. It is striking that this type of work, arising as it has from the outsourcing to the market of family care and which has in the past been a distinguishing feature of the city, is now an emerging source of employment in the rural world. Indeed, it suggests that the future of the village depends on its blurring the boundaries between city and rural existence (Omelchenko \& Poliakov, 2018) and becoming a more multifunctional area (Kasimis, et al., 2010). Although some of the interviewees acknowledge this type of occupation as a potential source of employment, most female interviewees do not appear to be considering this type of work for themselves at present and, perhaps not unsurprisingly, none of the males do it. This rejection is partly related to the major investment in education that predominates in most of the rural youth (and their families) in response to the lack of opportunities they see in the (maledominated) rural economy.

To bring about a change in this situation, better information needs to be offered to young people (both male and female) about the future potential of job opportunities in the care of old people, modifying the negative perception that is presently held and providing specific and ongoing training in this activity in order to promote professionalization in this field and thereby augment its attractiveness as an option.

The perception of the intensity of rural community bonds also appears to be an important 'stay' factor, complementing previous observations by Glendinning et al. (2003). Therefore, the promotion of youth associations would contribute to containing the population drain of young people. However, it should be additionally noted that remarkable efforts are being made by some interviewees to participate in associations and activities, which generate ties that contribute to the establishment of even deeper roots. In other words, feeling good in the community requires effort on the part of the rural youth.

Although the consumerist urban culture is critically an ever present and dominating force among the rural youth, post-materialist values were observed in the interviews too (Inglehart \& Welzel, 2005), along with the acclamation of 'the peace and quiet' of rural life (contrasted with the stress of urban life) or the possibility of a more 'natural' existence (since living in the village makes it easier to be in contact with nature). These desires are a reaction against the risks and complexities that an urban-centred modern life entails in spite of its opportunities (Caputo, 2001), and reflect the possibilities that the rural world today can offer young people. Assuredly, this vision of the rural world as a healthier and less dangerous space will have been strengthened by the Covid-19 pandemic, as it is the more densely populated areas that have been most negatively affected. A first sign that this is happening is the growing interest in rural properties in the real estate market (Idealista, 2020), though further confirmation and verification of this is required.

Finding the rural environment to be a less stressful place or where one can better satisfy the need for physical activity, which was remarked on by some youths, also bears witness to the relevance of the "embodied dimensions" of the relationship of rural youth with their village as a stay factor (Farrugia et al., 2016). This also confirms the feeling of freedom that the rural milieu inspires in youth by offering a different kind of space for leisure (Abbott-Chapman \& Robertson, 2015; O'Toole et al., 2010). That is, the village is not always perceived as a space of intense and negative social control. Moreover, protecting the natural environment and ensuring it can be 
enjoyed by investing in infrastructure are growth potential practices that should be considered in policies aimed at encouraging people to stay in rural areas.

Likewise, although the literature tends to underline the rejection by young females of the rural world (Nuttall, 2000), some of the young women interviewed do see certain advantages to life in the village, including its consideration as a safer and better place to bring up children. That is, villages are depicted here as more family-friendly places, which could be exploited by rural public administrators as a comparative advantage vis-á-vis the city. The overriding goal should be to promote a vision of life in rural communities that does not imply disconnection from the real or urban world but instead can be seen simply as another modern, alternative and even richer way of living.

The above directly calls for greater involvement on the part of public administrations. In this regard, the regional government of Castilla y León (Junta de Castilla y León, 2017) have proposed measures such as improving local transport to the city, maintaining basic services (pharmacies, etc.) or promoting entrepreneurship, which could contribute to reversing the negative perceptions held by youths in this study. However, these measures have either not been adequately evaluated and developed in coherent programmes (Llobregat, 2020) or simply entail one-off tax deductions when perhaps, given the gravity of the problem, it would be better to operate with a more interventionist focus as opposed to acting as mere facilitators of private initiatives. Proposals for the study area could be based on some of the programmes that have been developed in Aragón, a Spanish region with an equally problematic rural abandonment. There, the Spanish Ministry of Universities and UNED (a public university focused on distance learning) have plans to revitalize a rural area by creating in it a university-level education centre, training programmes to support the development of microenterprises, and a drone research centre. These initiatives will help in the creation of skilled professional jobs, which is one of the demands of our interviewees. There is also a plan to develop a local heritage research centre, contributing to promote the cultural values of the area as well as local identity and pride (Ministerio de Universidades, 2021).

Meanwhile, the Spanish Government has launched a programme called 'rural Erasmus', which aims to offer paid placements to university students in boroughs (with less than 5000 inhabitants) located in regions other than where the youth studies or is registered as living. The goal is to help them develop emotional ties that will favour their continuance in the rural environment (Ministerio para la Transición Ecológica, 2021). In this case, the programme is not looking for 'native' youths to remain in their village, but rather to repopulate it with 'non-native' youths. Nonetheless, a successful repopulation could also serve to attract back the youths who have left, something which would need to be evaluated in a future study.

All these action programmes are interesting as they offer a response to the problems seen in the interviews. That is, apart from generating economic structural changes, the symbolic capital of what is rural life needs to be promoted, along with positive emotions about the place as such emotions constitute the energy that nourishes bonds and ties (Collins, 2004), in this case to the village.

In terms of the generalizations of the results of the present study, the conclusions that have been drawn can be of help in the interpretation of similar contexts to those found in inland Spain, namely non-coastal rural areas of Europe with low levels of industrialization and extensive and poorly diversified agricultural activity.

\section{Acknowledgments}

This work was supported by the Diputación de Valladolid/ Provincial Government of Valladolid [Decreto 2014 de 24 de junio de 2016], as part of its IV Provincial Youth Plan 2015-2019. The aforementioned public sponsor had no influence on the design, collection or analysis of data. The content of this article is solely the responsibility of the authors and does not necessarily represent the official views of the Provincial Government of Valladolid. 
[1] Abbott-Chapman, J. \& Robertson, M. (2015). Youth Leisure, Places, Spaces and Identity. In Gammom, S. \& Elkington, S., eds., Landscapes of Leisure (pp. 123-134). London: Palgrave Macmillan UK. DOI: 10.1057/9781137428530_9.

[2] Albrecht, D. E. (1998). The Industrial Transformation of Farm Communities: Implications for Family Structure and Socioeconomic Conditions. Rural Sociology, 63(1), 51-64. DOI: 10.1111/j.1549-0831.1998.tb00664.x.

[3] Ames, P. (2013). Constructing new identities? The role of gender and education in rural girls' life aspirations in Peru. Gender and Education, 25(3), 267-283. DOI: 10.1080/09540253.2012.740448.

[4] Argent, N. \& Tonts, M. (2015). A Multicultural and Multifunctional Countryside? International Labour Migration and Australia's Productivist Heartlands. Population, Space and Place, 21(2), 140-156. DOI: 10.1002/psp.1812.

[5] Argent, N. \& Walmsley, J. (2008). Rural Youth Migration Trends in Australia: an Overview of Recent Trends and Two Inland Case Studies. Geographical Research, 46(2), 139-152. DOI: 10.1111/j.1745-5871.2008.00505.x.

[6] Arnalte, E. (2002). Pac y desarrollo rural: una relación de amor-odio. ICE Globalización y Mundo Rural, (803), 45-60.

[7] Atance, I., Martínez Jávega, M. T., Pujol, R. \& Urruela, J. (2010). La población rural en España: un enfoque a escala municipal. Economía Agraria y Recursos Naturales, 10(1), 3557. DOI: 10.7201/earn.2010.01.03.

[8] Bæck, U. D. (2004). The Urban Ethos. YOUNG, 12(2), 99-115. DOI: $10.1177 / 1103308804039634$.

[9] Beltrán Tapia, F. \& Martínez-Galarraga, J. (2015). Land access inequality and education in pre-industrial Spain [Discussion paper in Economic and Social History No. 137]. University of Oxford.

[10] Bernard, J. (2019). Families and local opportunities in rural peripheries: Intersections between resources, ambitions and the residential environment. Journal of Rural Studies, 66, 43-51. DOI: 10.1016/j.jrurstud.2019.01.025.

[11] Burch, D. \& Lawrence, G. (2013). Financialization in agri-food supply chains: private equity and the transformation of the retail sector. Agriculture and Human Values, 30(2), 247-258. DOI: $10.1007 / \mathrm{s} 10460-012-9413-7$.

[12] Camarero, L. (2000). Jóvenes sobre la tierra y el asfalto. Los ocios de los jóvenes rurales y urbanos. Estudios de Juventud, 50, 63-81.

[13] Camarero, L. (2017). Trabajadores del campo y familias de la tierra. Instantáneas de la desagrarización. Ager, (23), 163-195. DOI: 10.4422/ager.2017.01.

[14] Caputo, J. D. (2001). On religion. London: Routledge.

[15] Carlucci, M., Grigoriadis, E., Rontos, K. \& Salvati, L. (2017). Revisiting a Hegemonic Concept: Long-term 'Mediterranean Urbanization' in Between City Re-polarization and Metropolitan Decline. Applied Spatial Analysis and Policy, 10(3), 347-362. DOI: $10.1007 / \mathrm{s} 12061-016-9186-2$.

[16] Carr, P. \& Kefalas, M. (2009). Hollowing out the middle: the rural brain drain and what it means for America. Boston, Mass.: Beacon Press.

[17] Certeau, M. de \& Rendall, S. (1988). The practice of everyday life. Berkeley: University of California Press.

[18] Clapp, J. (2014). Financialization, distance and global food politics. The Journal of Peasant Studies, 41(5), 797-814. DOI: 10.1080/03066150.2013.875536. 
[19] Collantes, F., Pinilla, V., Sáez, L. A. \& Silvestre, J. (2014). Reducing Depopulation in Rural Spain: The Impact of Immigration. Population, Space and Place, 20(7), 606-621. DOI: $10.1002 / p s p .1797$.

[20] Collins, R. (2004). Interaction ritual chains. Princeton, N.J.: Princeton University Press.

[21] Conde, F. (2009). Análisis sociológico del sistema de discursos. Madrid: Centro de Investigaciones Sociológicas.

[22] Cook, J. \& Cuervo, H. (2020). Staying, leaving and returning: Rurality and the development of reflexivity and motility. Current Sociology, 68(1), 60-76. DOI: $10.1177 / 0011392118756473$.

[23] Corbett, M. J., Corbett, N. (2018). Giftedness: A Sociological Critique From a Rural Perspective. Critical Education, 9(1). DOI: 10.14288/ce.v9i1.186273.

[24] Corbett, M. J. (2010). Standardized individuality: Cosmopolitanism and educational decisionmaking in an Atlantic Canadian rural community. Compare, 40(2), 223-237. DOI: 10.1080/03057920903546088.

[25] Cuervo, H. \& Wyn, J. (2012). Young people making it work: continuity and change in rural places. Melbourne: Melbourne University Publishing.

[26] Cummins, H. (2009). Rural children's perceptions of life on the land in Southwestern Ontario. Canadian Geographer, 53(1), 63-83. DOI: 10.1111/j.1541-0064.2009.00237.x.

[27] Dahlström, M. (1996). Young women in a male periphery - Experiences from the Scandinavian north. Journal of Rural Studies, 12(3), 259-271. DOI: 10.1016/07430167(96)00018-6.

[28] Donato, K. M., Tolbert II, C. M., Nucci, A. \& Kawano, Y. (2007). Recent Immigrant Settlement in the Nonmetropolitan United States: Evidence from Internal Census Data. Rural Sociology, 72(4), 537-559. DOI: 10.1526/003601107782638666.

[29] Elder, G. H. \& Conger, R. D. (2000). Children of the Land: Adversity and Success in Rural America. Chicago: The University of Chicago Press.

[30] Fairclough, N. (2003). Analysing discourse. London: Routledge.

[31] Farrugia, D. (2016). The mobility imperative for rural youth: the structural, symbolic and nonrepresentational dimensions rural youth mobilities. Journal of Youth Studies, 19(6), 836-851. DOI: 10.1080/13676261.2015.1112886.

[32] Farrugia, D., Smyth, J. \& Harrison, T. (2014). Rural young people in late modernity: Place, globalisation and the spatial contours of identity. Current Sociology, 62(7), 1036-1054. DOI: $10.1177 / 0011392114538959$.

[33] Farrugia, D., Smyth, J. \& Harrison, T. (2016). Affective Topologies of Rural Youth Embodiment. Sociologia Ruralis, 56(1), 116-132. DOI: 10.1111/soru.12077.

[34] Gabriel, M. (2002). Australia's regional youth exodus. Journal of Rural Studies, 18(2), 209212. DOI: 10.1016/S0743-0167(01)00039-0.

[35] Garrido, L., González, J. J. \& Muñoz, J. (2020). Mercado de trabajo y clases sociales. In González, J. J., ed., Cambio social en la España del siglo XXI (pp. 221-249). Madrid: Alianza Editorial.

[36] Ghannam, F. (2011). Mobility, liminality, and embodiment in urban Egypt. American Ethnologist, 38(4), 790-800. DOI: 10.1111/j.1548-1425.2011.01337.x.

[37] Gibbs, G. (2007). Analysing qualitative data. London: Sage.

[38] Glendinning, A., Nuttall, M., Hendry, L., Kloep, M. \& Wood, S. (2003). Rural Communities and Well-Being: A Good Place to Grow Up? The Sociological Review, 51(1), 129-156. DOI: 10.1111/1467-954X.00411.

[39] González Regidor, J. (2017). Desarrollo rural en España: una política de estado inaplazable. 
Documentación Social, (185), 103-119.

[40] Halliday, J. \& Little, J. (2001). Amongst Women: Exploring the Reality of Rural Childcare. Sociologia Ruralis, 41(4), 423-437. DOI: 10.1111/1467-9523.00192.

[41] Inglehart, R. \& Welzel, C. (2005). Modernization, Cultural Change, and Democracy. Cambridge University Press. DOI: 10.1017/CBO9780511790881.

[42] Kasimis, C., Papadopoulos, A. G. \& Pappas, C. (2010). Gaining from rural migrants: Migrant employment strategies and socioeconomic implications for rural labour markets. Sociologia Ruralis, 50(3), 258-276. DOI: 10.1111/j.1467-9523.2010.00515.x.

[43] Kilpatrick, S., Johns, S., Vitartas, P. \& Homisan, M. (2011). Mobile skilled workers: Making the most of an untapped rural community resource. Journal of Rural Studies, 27(2), 181190. DOI: 10.1016/j.jrurstud.2011.01.003.

[44] King, R., Thomson, M., Fielding, T. \& Warnes, T. (2006). Time, generations and gender in migration and settlement. In Pennix, R., Berger, M. \& Kraal, K., eds., The Dynamics of International Migration and Settlement in Europe (pp. 233-268). Amsterdam: Amsterdam University Press.

[45] Kirkpatrick Johnson, M., Elder Jr., G. H. \& Stern, M. (2005). Attachments to Family and Community and the Young Adult Transition of Rural Youth. Journal of Research on Adolescence, 15(1), 99-125. DOI: 10.1111/j.1532-7795.2005.00088.x.

[46] Leyshon, M. (2011). The struggle to belong: young people on the move in the countryside. Population, Space and Place, 17(4), 304-325. DOI: 10.1002/psp.580.

[47] Llobregat, C. (2020). Informe Soria. Análisis de la despoblación rural para mejorar la acción pública [Master thesis]. Barcelona: University of Barcelona.

[48] Llopis-Goig, R. \& Vilanova, A. (2015). Spain: A sociological analysis of the evolution and characteristics of running. In Scheerder, J., Breedveld, K. \& Borgers, J., eds., Running across Europe. Basingstoke: Palgrave Macmillan. DOI: 10.1057/9781137446374.0016.

[49] Mamonova, N. (2016). Naive Monarchism and Rural Resistance in Contemporary Russia. Rural Sociology, 81(3), 316-342. DOI: 10.1111/ruso.12097.

[50] Margaras, V. (2016). Sparsely populated and underpopulated areas [briefing]. Brussel: European Parliament.

[51] McLaughlin, D. K., Shoff, C. M. \& Demi, M. A. (2014). Influence of Perceptions of Current and Future Community on Residential Aspirations of Rural Youth. Rural Sociology, 79(4), 453-477. DOI: 10.1111/ruso.12044.

[52] Molinero, F. (2019). El espacio rural de España: evolución, delimitación y clasificación. Cuadernos Geográficos, 58(3), 19-56. DOI: 10.30827/cuadgeo.v58i3.8643.

[53] Molinero, F., Baraja, E. \& Herrero, D. (2016). La modernización de la explotación agraria en Castilla y León: empresarios agrarios y propietarios agrícolas. In Vera Rebollo, J. F., Olcina Cantos, J. \& Hernández Hernández, M., eds., Paisaje, cultura territorial y vivencia de la geografía (pp. 629-652). Alicante: Servicio de Publicaciones de la UA.

[54] Moreno, A. (2018). The youth emancipation in Spain: a sociodemographic analysis, International Journal of Adolescence and Youth, 23(4), 496-510. DOI: 10.1080/02673843.2018.1438299.

[55] Niedomysl, T. \& Amcoff, J. (2011). Is There Hidden Potential for Rural Population Growth in Sweden? Rural Sociology, 76(2), 257-279. DOI: 10.1111/j.1549-0831.2010.00032.x.

[56] Nieto Masot, A., Engelmo Moriche, Á., Cárdenas Alonso, G. \& Mora Aliseda, J. (2019). Índice de ruralidad para los municipios españoles (Censo del 2011). In Cejudo García, E., Navarro Valverde, F. A. \& Camacho Balleste, J. A., eds., Nuevas realidades rurales en tiempos de crisis. Territorios, actores, procesos y políticas (pp. 223-234). Universidad de Granada.

[57] Noack, E. (2011). Are Rural Women Mobility Deprived? - A Case Study from Scotland. 
Sociologia Ruralis, 51(1), 79-97. DOI: 10.1111/j.1467-9523.2010.00527.x.

[58] Nuttall, M. (2000). Crisis, risk and deskilment in North-East Scotland's fishing industry. In Symes, D., ed., Fisheries Dependent Regions (pp. 106-115). Oxford (UK): Blackwell Science.

[59] O'Toole, K., Dennis, J., Kilpatrick, S. \& Farmer, J. (2010). From passive welfare to community governance: Youth NGOs in Australia and Scotland. Children and Youth Services Review, 32(3), 430-436. DOI: 10.1016/j.childyouth.2009.10.016.

[60] Omelchenko, E. \& Poliakov, S. (2018). Everyday Consumption of Russian Youth in Small Towns and Villages. Sociologia Ruralis, 58(3), 644-664. DOI: 10.1111/soru.12197.

[61] Öztürk, M., Hilton, A. \& Jongerden, J. (2014). Migration as Movement and Multiplace Life: Some Recent Developments in Rural Living Structures in Turkey. Population, Space and Place, 20(4), 370-388. DOI: 10.1002/psp.1828.

[62] Pedersen, H. D. (2018). Is Out of Sight out of Mind? Place Attachment among Rural Youth Out-Migrants. Sociologia Ruralis, 58(3), 684-704. DOI: 10.1111/soru.12214.

[63] Pini, B. \& Leach, B. (2011). Transformations of Class and Gender in the Globalized Countryside: An Introduction. In Pini, B. \& Leach, B., eds., Reshaping gender and class in rural spaces (not paged). London: Routledge.

[64] Pinilla, V. \& Sáez, L. A. (2017). La Despoblación Rural En España: Génesis De Un Problema Y Políticas Innovadoras [Working paper]. Zaragoza: CEDDAR.

[65] Powell, M. A., Taylor, N. \& Smith, A. B. (2013). Constructions of rural childhood: challenging dominant perspectives. Children's Geographies, 11(1), 117-131. DOI: $10.1080 / 14733285.2013 .743285$.

[66] Prieto-Lara, E. \& Ocaña-Riola, R. (2010). Updating Rurality Index for Small Areas in Spain. Social Indicators Research, 95(2), 267-280. DOI: 10.1007/s11205-009-9459-0.

[67] Recaño, J. (2017). La sostenibilidad demográfica de la España vacía. Perspectives Demogràfiques, 1-4. DOI: 10.46710/ced.pd.esp.7.

[68] Ricoeur, P. (1976). Interpretation Theory: Discourse and the Surplus of Meaning. Fort Worth: Texas Christian University Press.

[69] Rudkin, L., Elder, G. H. \& Conger, R. (1994). Influences on migration intentions of rural adolescents. In Mandell, N., Porter, E., Tesson, G. \& Lewko, J., eds., Macro-Micro Connections in the Pathways to Adulthood Vol. 6. Bingley: Emerald Group Publishing Limited.

[70] Rugg, J. \& Jones, A. (1999). Getting a job, finding a home: rural youth transitions. Bristol: Policy Press.

[71] Sampedro, R. (2000). Mujeres jóvenes en el mundo rural. Revista de Estudios de Juventud (48), 83-90.

[72] Sampedro, R. (2008). Como ser moderna y de pueblo a la vez. Revista de Estudios de Juventud (83), 179-194.

[73] Shaw, J. M. (1979). Rural deprivation and planning. Norwich: Geo Abstracts Ltd.

[74] Stockdale, A. (2006). Migration: Pre-requisite for rural economic regeneration? Journal of Rural Studies, 22(3), 354-366. DOI: 10.1016/j.jrurstud.2005.11.001.

[75] Storey, P. \& Brannen, J. (2000). Young people and Transport in Rural Areas [Report]. York: Joseph Rowntree Foundation.

[76] Terres, J.-M., Scacchiafichi, L. N., Wania, A., Ambar, M., Anguiano, E., Buckwell, A., Coppola, A., Gocht, A., Nordtröm Källström, H., Pointereau, P., Strijker, D., Visek, L. \& Zobena, A. (2015). Farmland abandonment in Europe: Identification of drivers and indicators, and development of a composite indicator of risk. Land Use Policy, 49, 20-34. DOI: 10.1016/j.landusepol.2015.06.009. 
[77] Thissen, F., Fortuijn, J. D., Strijker, D. \& Haartsen, T. (2010). Migration intentions of rural youth in the Westhoek, Flanders, Belgium and the Veenkoloniën, The Netherlands. Journal of Rural Studies, 26(4), 428-436. DOI: 10.1016/j.jrurstud.2010.05.001.

[78] Tickamyer, A. R. \& Duncan, C. M. (1990). Poverty and Opportunity Structure in Rural America. Annual Review of Sociology, 16(1), 67-86. DOI: 10.1146/annurev.so.16.080190.000435.

[79] Timmermans, S. \& Tavory, I. (2012). Theory Construction in Qualitative Research: From Grounded Theory to Abductive Analysis. Sociological Theory, 30(3), 167-186. DOI: $10.1177 / 0735275112457914$.

[80] Trell, E.-M., van Hoven, B. \& Huigen, P. (2012). 'It's good to live in Järva-Jaani but we can't stay here': Youth and belonging in rural Estonia. Journal of Rural Studies, 28(2), 139-148. DOI: 10.1016/j.jrurstud.2012.01.023.

[81] Ulrich-Schad, J. D., Henly, M. \& Safford, T. G. (2013). The Role of Community Assessments, Place, and the Great Recession in the Migration Intentions of Rural Americans. Rural Sociology, 78(3), 371-398. DOI: 10.1111/ruso.12016.

[82] Urry, J. (2007). Mobilities. Cambridge: Polity.

[83] van Dalen, H. P. \& Henkens, K. (2013). Explaining emigration intentions and behaviour in the Netherlands, 2005-2010. Population Studies, 67(2), 225-241. DOI: $10.1080 / 00324728.2012 .725135$.

[84] Veitch, P. C. (1995). Anticipated response to three common injuries by rural and remote area residents. Social Science and Medicine, 41(5), 739-745. DOI: 10.1016/02779536(94)00387-9.

[85] Wiest, K. (2016). Migration and everyday discourses: Peripheralisation in rural SaxonyAnhalt from a gender perspective. Journal of Rural Studies, 43, 280-290. DOI: 10.1016/j.jrurstud.2015.03.003.

Other sources

[86] Castilla y León Televisión (2021). Bases VII Premios Surcos 2022. Retrieved September 5, 2021, from CYLTV website: https://www.cyltv.es/ficha/premios-surcos.

[87] ESPON (2018). PROFECY-Processes, Features and Cycles of Inner Peripheries in Europe. Luxembourg. Retrieved from https://www.espon.eu/handbooks\#toc0.

[88] Eurostat (2021a). Estimated average age of young people leaving the parental household by sex. Retrieved Septembre 7, 2021, from: https://ec.europa.eu/eurostat/databrowser/view/yth_demo_030/default/table?lang=.

[89] Eurostat (2021b). Youth unemployment rate by sex, age and country of birth. Retrieved Septembre 7, 2021, from: https://ec.europa.eu/eurostat/databrowser/view/yth_empl_100/default/table?lang=en.

[90] Eurostat (2021c). Young temporary employees as percentage of the total number of employees, by sex, age and country of birth. Retrieved Septembre 7, 2021, from: https://ec.europa.eu/eurostat/databrowser/view/yth_empl_050/default/table?lang=en.

[91] FAD Reina Sofía (2021a). Índice sintético de desarrollo juvenil comparado. Tasa (\%) de desempleo. Retrieved Septembre 7, 2021, from: https://www.adolescenciayjuventud.org/indicador/desempleo/.

[92] FAD Reina Sofía (2021b). Índice sintético de desarrollo juvenil comparado. Tasa (\%) de temporalidad (15-29 años). Retrieved Septembre 7, 2021, from: https://www.adolescenciayjuventud.org/indicador/tasa-de-temporalidad/.

[93] Idealista (2020). El interés por comprar vivienda en municipios de menos de 5.000 habitantes 
aumenta. Retrieved March 20, 2021, from Idealista News website: https://www.idealista.com/news/inmobiliario/vivienda/2020/08/11/786612-el-interes-porcomprar-vivienda-en-municipios-de-menos-de-5-000-habitantes-aumenta.

[94] Injuve (2021). Informe Juventud en España 2020. Madrid. Retrieved from http://www.injuve.es/sites/default/files/adjuntos/2021/03/informe_juventud_espana_2020.p df.

[95] Junta de Castilla y León (2017). Agenda para la población de Castilla y León. 2010-2020. Valladolid. Retrieved from: https://www.jcyl.es/web/es/agendapoblacion/agenda-parapoblacion/agenda-poblacion-2010-2020.html.

[96] Ministerio de Universidades (2021). El Ministerio de Universidades y la UNED presentan un proyecto piloto en Teruel para hacer frente a la España despoblada. Retrieved September 5, 2021, from Spanish Ministry of University website: https://www.universidades.gob.es/portal/site/universidades/menuitem.43f867cc076c14d18 5cacc2c026041a0/?vgnextoid=b1115b62f1a69710VgnVCM1000001d04140aRCRD.

[97] Ministerio para la Transición Ecológica (2021). Teresa Ribera presenta el Programa Campus Rural. Retrieved September 6, 2021, from Spanish Ministry for the Ecological Transition website: https://www.miteco.gob.es/es/prensa/210701 npcampusrural_tcm30-528963.pdf.

[98] UN (2019). World Urbanization Prospects 2018: Highlights. New York. Retrieved from https://population.un.org/wup/Publications/Files/WUP2018-Highlights.pdf. 